\title{
How Important Are Same-Gender Role Models to Middle School Girls? Five Characteristics of Mentors Who Sustain Middle-School Girls' Interest in Science Careers
}

\author{
Donna Farland-Smtih (Corresponding author) \\ The Ohio State University-Mansfield, 1680 University Drive \\ Mansfield, OH 44906, USA \\ Tel: 419-961-2885Ｅ-mail: farland-smith.1@osu.edu
}

Received: April 6, 2014 Accepted: April 21, 2014 Published: August 29, 2014

doi:10.5296/jet.v2i1.5423 URL: http://dx.doi.org/10.5296/jet.v2i1.5423

\begin{abstract}
Content area specialists (scientists) are often recruited to address issues of retention and recruitment in science education. Yet, guidance in the selection of these types of mentors or role models remains unpublished. One strategy for selecting scientists/role models is to select them on the basis of same gender as the participants. This study examined eight scientists (four gender-matched and two gender-mismatched) as they worked with middle-school girls. The data was collected during 'Side-by-Side' interaction with content specialists and has implications for classroom practice. These experiences demonstrate that working with highly-skilled, highly-trained scientists reveal that unless the scientists understand the difference between content knowledge and pedagogical content knowledge, they are not open or sometimes unwilling to learning science-content pedagogy. The Mentor-Approach-to-Teaching Continuum as developed in this study can be used to better help teachers understand and assist scientists in their teaching roles. As middle-school girls' experiences with science content specialists helped the students shape their perception of scientists, careful consideration, preparation, and maintenance of these relationships were critical to the girls sustaining an interest in science. This paper provides suggestions for helping teachers achieve success with science content specialists and provides answers to the question of the importance of same-sex role models in mentoring young girls in science. It also identifies five characteristics educators should look for in selecting science mentors who would be successful in broadening students' perceptions of scientists.
\end{abstract}

Keywords: middle school, girls, mentors, science 
What makes someone a good science mentor or role model? Is it their education or experience? Is it their expertise or the knowledge they possess? Do gender-matched role models offer more benefits than gender-mismatched role models? If so, what are those benefits, and are they gender specific? These questions have become increasingly important as reform in science education calls for scientists to enter classrooms to solve some of the pressing issues in science education, specifically, recruitment and retention. Unfortunately, many students who initially show an interest in science do not remain in science fields. As more students choose to pursue interests unrelated to science, there is growing concern about attracting future scientists, especially females, in the United States.

Recently, President Barack Obama, in the National Math and Science Initiative, requested that all scientists do their part to help young students achieve better grades in science (Gibbs, 2010). He also suggested that scientists visit a classroom from time to time as a mentor. This recommendation is built on the assumption that any scientist who interacts with students will be beneficial to the students. However, these mentor relationships may not be as beneficial as they have the potential to be, because not every scientist can relate to children in an age-appropriate way. Without specialized training, some scientists may not be able to discuss their field of study in a way that does not reinforce common stereotypes about scientists. Without clear boundaries or definitions of the characteristics of successful mentors, all willing mentors may be welcomed into the classroom; but the reality is that some mentors will be more successful working with students than others. That said, the indiscriminate use of visiting scientists in the classroom should be cautioned, because all scientists don't necessarily make good mentors.

Classroom teachers are limited by time and responsibility. They must attend to day-to-day issues while worrying about meeting instructional standards and the requirements of end-of-course tests. As a result, classroom teachers need guidance in working with appropriate science content specialists for their students. As this will maximize the potential influence mentor scientists have on students' understanding of who does science, where science is done, and what scientists do. This paper explores the approaches of content specialists when working with middle school girls and suggests as to how scientists should be prepared to serve in these mentorship roles.

\section{Literature Review}

Reform in science education has always been a top priority for science educators and an interest of the Obama presidential administration in the Educate to Innovate Campaign( ). Recruitment and retention of students are the two main areas targeted for reform, because many students who initially display an interest in science do not remain in science fields. As more students choose to pursue interests unrelated to science, there is growing concern about attracting future scientists, especially females, in the United States. The lack of female scientists has been a concern in the science and science-education fields for some time, as women are under-represented in the profession (Buck et al., 2007). Professional scientists interacting with students in a formal, classroom setting is often suggested as a possible solution. Yet this approach remains under-researched from the perspective of the classroom 
teacher and the benefit students derive from interacting with a scientist.

Role models have long been thought to shape adolescent development, aspirations, and achievement by providing positive examples of what could be (King \& Multon, 1996; Nauta, Epperson, \& Kahn, 1998). Role models can be family members or teachers who directly and indirectly affect students' school experiences, self-esteem, and educational and occupational outcomes (Evans, 1992; Galbo, 1989; Solnick, 1995; Wilcoxson \& Phelps, 2004). The following studies emphasized the importance of a gender- and/or ethnic-matched role model: Evans (1992), Karunanayake and Nauta (2004), and Zirkel (2002). These studies claim that gender-matched role models send students messages that gender-mismatched role models do not, and therefore, are more valuable. Lockwood (2006) found that women more often than men select gender-matched career role models. The study also emphasized the value of having a female, gender-matched role model who has achieved success in a traditionally male-dominated profession.

The research on visiting-scientist programs is built on the assumption that a scientist in the classroom will benefit children's perceptions of who scientists are and the work they do. Bozdin and Gerhinger (2001) and Flick (1990) reported that visits from scientists in classrooms resulted in a decrease in many stereotypical beliefs about scientists, indicating that children's images of scientists can indeed be influenced by a visit from a scientist. However, it cannot be assumed that these relationships are successful in every classroom.

While much is known about mentoring new teachers in science, the research concerning scientist mentoring individual students remains unexamined. A science camp was selected as the context for this study, as it has been established that it is successful in establishing a transformative experience for young female students, broadening their perceptions about scientists (Author, 2009). The data collected over the last four years appears to be enough to start guiding educators towards selecting, preparing, and maintaining successful interactions between middle-school girls and working scientists.

The National Science Education Standards (1996, 2012), AAAS (1993) Benchmarks for Scientific Literacy (Project 2061) were used as a framework for this summer camp/"Side-by-Side" experience because they each include Science as a Human Endeavor. The National Science Education Standards (1996, 2012), advocate that Science as a Human Endeavor should be taught as early as the elementary grades, "in order to provide a foundation for the development of sophisticated ideas related to the history and nature of science that will be developed in later years" (NRC, 1996, p. 141). The narrow and erroneous impression of science held by many students has, in part, inspired science reformers to create The National Science Education Standards (NSES) (National Research Council [NRC], 1996). The standards recommend the teaching of specific science content and science processes, as well as emphasizing the human element of scientific enterprise.

Many students view scientists as being quite different from people working in other jobs. Additionally, they often hold highly stereotypical and inaccurate views of scientists and the work they do. In studies spanning five decades, it has been noted that students typically portray scientists as males confined to a laboratory, surrounded by dangerous chemicals, and 
conducting laborious experiments (Barman, 1997; Chambers, 1983; Finson, 2002; Fort \&Varney, 1989; Mead \& Metraux, 1957; Schibeci \&Sorenson, 1983). These inaccurate views of scientists are widely held by students from elementary through secondary school (Barman, 1996; Chambers, 1983).

The Standards (1996) focus on the following four human dimensions of science:

1. Science and technology have been practiced by people for a long time.

2. Men and women have made a variety of contributions throughout the history of science and technology.

3. Science will never be finished. Although men and women using scientific inquiry have learned much about the objects, events and phenomena in nature, much more remains to be understood.

4. Many people choose science as a career and devote their entire lives to studying it. Many people derive great pleasure from doing science. (NRC, 1996, p.141).

These four aspects of "Science as a Human Endeavor" should be explicitly taught to young children. The NSES recommend that students understand that science and technology have been practiced for a long time (NRC, 1996). Students also need to understand not only the key concepts and principles of science and how scientific knowledge is applied, but also the cultural and social contexts within which science is advanced (Kafai \& Gilliland-Swetland, 2000).

The NSES recommend that students become aware of the variety of contributions made by men and women scientists. Often, children's books and their pictures portray scientists as secretive and in pursuit of the "one answer to everything" (Chambers, 1983). For example, when children draw pictures of scientists, they often include captions such as, "I am going to blow up the world," or "Eureka, I've found the cure!" indicating the child's limited knowledge of scientists. Further, these captions suggest that scientists are always inventing or working on immense or dangerous projects, which is certainly not the case with most scientists.

Third, the NSES recommend that students grasp the idea that science will never be finished. Kuhn (1972) suggested that science textbooks may actually impede progress toward this aspect of scientific literacy. Science texts are beneficial in that they allow students to categorize an immense amount of factual information, but one of the negative effects of textbooks is that they give students the impression that everything they need to know is contained within the pages of the book. Knowledge contained in a book may suggest that science has been completed and the students' role is merely to study the contents of the book and regurgitate facts without considering additional possibilities.

Commonly held stereotypic images about scientists are often in direct opposition to what students are supposed to be able to understand about scientists. This is outlined by the fourth component of NSES (1996), which states "that many people derive great pleasure in doing science" (p.141). However, unless students have multiple interactions with scientists, they 
may never come to accept these four aspects of the human side of science. Thus, the summer-camp experience was designed around these four NSES tenets. The "Side-by-Side" experiences described in this paper provided a means for middle-school girls to experience first-hand these four dimensions of science. However, providing these four dimensions required careful thought and preparation by the mentors for them to be successful with the students.

In this paper, one key question was addressed in the examination of the eight scientists and their role with middle school girls: 1) How did the science content specialists approach their opportunity to teach middle-school girls? This question was asked in hopes of determining quality and effective future camp experiences. In addition, it was even more important in forming guidelines for classroom teachers that could be used in preparing, and maintaining successful personal and social interactions between middle-school girls and content specialists.

\section{Overview of the Research Context}

Eight professional scientists (six females and two males) were involved with 100 middle-school girls in a multi-year collaboration known as the "Side-by-Side" experience. The camp was held on the campus of a large Midwest regional university to take advantage of the university's resources, yet offer a more rural setting with a stream and wetlands for fieldwork.

\subsection{Middle-School Girls}

The girls attending the camp were drawn randomly from several public, private, and home-school populations. Unfortunately, the area where the girls live is now part of an economically depressed region whose economy was once based on one of three largest U. S. automakers. With the closing of a major auto plant, the area is now severely economically depressed. The unemployment rate is above the 10.5 percent national average, and the median family income is $\$ 37,541$. "Side-by-Side with Scientists" camp was held each year for the past three years during the last two weeks of July. The girls were taught by five different scientists over the period of one week. During each week of camp up to 25 different girls participated for a total of 100 different campers over the three-year span. Some of the same girls returned to camp from year to year.

\subsection{Selecting Science Content Specialists}

Each scientist was a university professor and brought his/her own style of teaching and personality to the classroom. The professors wore name tags identifying them as a doctor (Ph.D), with their first name printed large and bold, followed by their last name in smaller print. The was so the girls could address the scientists by their first name, i.e. Dr. Dawn as a means of seeing them as "normal" people. The order in which the scientists presented their lessons was different each week to accommodate the scientists' individual work schedules. Figure 1 below is an example from year one. All scientists presented prepared, interactive laboratory or field work activities with the students. 


\begin{tabular}{|l|c|c|c|c|c|}
\hline & Monday & Tuesday & Wednesday & Thursday & Friday \\
\hline Week 1 & Physics & Plant Ecology & Wetlands Ecology & Physical Anthropology & Chemistry \\
\hline Week 2 & Physical Anthropology & Chemistry & Wetlands Ecology & Plant Ecology & Physics \\
\hline
\end{tabular}

Figure 1. Sample Schedule of Year One

It is important to mention that all scientists were extremely interested in being involved with the summer camp, and were enthusiastic, willing participants. A description follows regarding the scientists' -content background, rank at their university, time associated with the camp, and how they presented and/or prepared their activities with the girls.

\subsection{Mentor Scientist \#1, Dr. Darlene}

Darlene (participated two years) is an assistant professor of anthropology. She is a Caucasian female who grew up in the U.S., earning a doctorate in Ecology, Evolution, and Animal Behavior. She studies baboons in Botswana, and has performed surveys of primates in South Africa and Zanzibar. Dr. Darlene shared her work with the girls as a physical anthropologist. Both years, she began her lesson by showing many pictures and telling stories about her work in Africa studying the calls of various types of baboons. After her introduction the first year, students studied the behavior of three dogs by designing an investigation to see which type of treat the dogs liked best. In the second year, she led the girls to investigate sound using an inquiry-based method. The girls learned about sound in the forest and in the lab by utilizing Dr. Darlene's audio equipment.

\subsection{Mentor Scientist \#2, Dr. Juan}

Juan (participated two years) is an assistant professor of earth science from Brazil. He holds a Ph.D in Coral Reef Ecology and Nutrient Biogeochemistry, and currently studies the hydrology and geochemistry of the Clear Fork River in Ohio. The first year, he introduced the girls to the age of the earth using his soil samples, and the girls learned about dinosaur fossils through a cookie paleontology activity. The second year, he did many different activities, each designed to broaden the girls' understanding of earth science. Some of these activities included examining the relative size and distance of the planets in the solar system, as well as studying the earth's atmosphere and clouds.

\subsection{Mentor Scientist \#3, Dr. James}

James (participated four years) is a full professor with a Ph.D in Aquatic Zoology who studies invasive species of wetland grasses. He began his sessions with the girls by sharing his research. He always designs an investigation incorporating problem-based learning strategies. For example, to create a mock mystery, he asked the head of security at the university to come to class and tell the girls there had been a fish kill on campus. He said that he needed their help to solve the mystery of what had happened to the fish. A short time later, the officer returned to class with a suspect in hand cuffs. The officer asked the girls to figure out what the suspect had done to kill the fish. The girls were not initially told this was a mock fish kill, but they soon figured it out after finding paper fish scattered along a stream. The girls were 
very curious and determined to solve the mystery. While they were in the stream, they ran several tests and gathered evidence for their case against the suspect.

\subsection{Mentor Scientist \#4, Dr. Debbie}

Debbie (participated two years) is an assistant professor with a Ph.D in Environmental Sciences, studying soils in local wetlands. In an effort to get the girls outside and investigating, she identified five different soil types within range of the camp, and led the girls to gather and analyze soil samples from each site.

\subsection{Mentor Scientist \#5, Dr. Francine}

Dr. Francine (participated four years) is an Associate Professor of Chemistry. She is a Caucasian female who grew up in the U.S., and who studies the benefits of black raspberries to cancer patients. Due to the extensive activities she led in the class, Francine did not share much information about her work, nor did her fellow chemists who assisted with the lesson. On this day of camp, the girls were introduced to a mock crime-scene investigation in the chemistry lab. A "Dr. James" had been kidnapped, and the girls gathered evidence they then analyzed by performing six to nine chemical tests. Using the scenario provided by the instructors, the girls actively worked to solve the crime.

\subsection{Mentor Scientist \#6, Dr. Geraldine}

Geraldine (participated three years) is an Assistant Professor of Physics who grew up in Romania. Her Ph.D is in physics, and she studies Nuclear Structure Theory. The activities Geraldine led were based on college labs, and included topics such as pinhole cameras, circuits, and electricity. With the help of the camp director, she designed age-appropriate activities for the girls using a scale and elevator for measuring weight and weightlessness. In addition, she led an inquiry-based session on the physics of a working carwash.

\subsection{Mentor Scientist \#7, Scientist Jane}

Jane (participated two years) also introduced the girls to physics. The girls used motion detectors and computers to make graphs of the time and distance objects traveled. These activities were based on a college lab. Jane also shared her story of how she became interested in science and ultimately rose to the rank of a university teacher.

\subsection{Mentor Scientist \#8, Dr. Christy}

Christy (participated one year) is a plant reproductive ecologist who began her lesson with pictures and stories about her travels to tropical places. To help the girls learn about plants, she guided the students through several plant dissections. Later in the day, the students conducted their own pollination field studies in the university's wetlands.

In addition to the eight scientists, two licensed teachers and the camp director/researcher were present each day of the camp. The teachers facilitated activities and transitions between activities. The researcher has an Ed.D in mathematics and science education, and was a science methods professor for the university. She took field notes and assisted with activities when needed. She also greeted the girls each morning as they were dropped off at camp, 
collected data, and oversaw all aspects of camp. In seasons two through four, two additional helpers (high-school students too old to attend the camp) participated as assistants.

\section{Method}

This investigation of the eight scientists into their role with the middle school girls was conducted over a four- year period. Data collection began several months before the first science camp with an initial meeting between the camp director and each scientist. All scientists worked with the camp director/researcher to develop lessons before each camp (year) experience. This usually involved the scientist suggesting a lesson idea to the camp director, then working with the director to ensure science content relevant to the standards, and age-appropriateness of the activity or activities. The director/researcher took notes on each visit with each scientist in an effort to build a repository of data. The proposed approach of each scientist was then examined.

\subsection{Preparation: Initial Meetings with Scientists}

The focus of the initial meetings was to answer the scientists' questions and assist them in lesson construction. The length of these meetings, the general discussion, and the individual scientist's overall enthusiasm were recorded. The director/researcher listened to each scientist's lesson idea and discussed the time he or she was planning to spend with the girls during a one-day, six-hour time span. The director/researcher, using models for classroom inquiry and instruction, attempted to guide the scientists to enhance their lessons by using the five "Es" of the Learning Cycle: engage, explore, explain, expand, and evaluate (Karplus, 1970). The only requirement was that the scientists engage the girls in real-world science, similar to the work the scientists conducted in their particular field of study.

The scientists were specifically instructed to engage or set up motivations to initiate or sustain the girls' interest in inquiry. One way in which they could do this was to set up central questions for the girls to investigate and answer. Next, mentors were guided to explore with the girls, and how that concept might look in a middle-school classroom setting. These would be opportunities for students to investigate the central question through student-centered experiences. Scientists were then asked to use guided questioning in a way that would help students explain or uncover the standards-based concept or skill which the lesson was designed to teach. Fourthly, the scientists were guided to help students expand or conceptualize their ideas in an effort to deepen their understanding of the prescribed concepts and/or skills around which the lesson was constructed. Lastly, the scientists were asked to evaluate or assess the learning as the students conducted their inquiry experience.

Following this initial contact with the researcher/camp director, each scientist had different levels of follow-up contact. For example, before the first year's camp experience, Dr. Darlene required four meetings to conceptualize her idea of what she wanted to present to the students. Many emails and phone calls were made in preparing for the camp. Dr. Francine, on the other hand, did not initiate any additional contact other than to ask for materials. Dr. James, because he didn't want to offer the same experience to the girls more than once, required three meetings and discussions to form his ideas. Contact with Dr. Juan and Dr. Debbie only 
involved the initial meetings. Scientist Jane and Dr. Christy each required one initial meeting to conceptualize their ideas.

\subsection{Methods Used During the Camp}

During the "Side-by-Side" experience with the girls (two consecutive weeks in July), the researcher recorded field notes/observations of the interactions between the mentor scientists and the students, adding it to the repository of data for each mentor scientist. The researcher observed general classroom interactions between the girls and the scientists, focusing on interactions both personal (one-on-one) and in the social context of the entire camp (whole class), as a means of identifying the characteristics of the most successful content specialists. No special protocol was developed for this, instead general notes of what transpired were taken. Things that the scientists did and did not do with the girls were also recorded.

Since the camp was designed to take place during two consecutive weeks, the researcher/director had a chance to follow-up with scientists after week one to see if what support might be needed for week two. This was also a time to reflect on week one's lesson and modify, if necessary, the lesson for week two. In the four years of summer camp, only two mentors took advantage of this reflection time with the director to completely change their lesson for the second week.

Following each camp experience, each scientist was interviewed while reflecting on and discussing his/her own experience. These interviews were recorded, coded, and analyzed for themes of qualities or traits. Each teacher or camp staff who worked at the science camp with individual scientists was interviewed following his/her experiences and notes were taken on particular scientists. That information was added to the repository of data for each mentor scientist. These methods were repeated for four consecutive summers. Data collection was triangulated through the different methods used in collection (e.g., field notes, interviews with camp staff and scientists, and notes from meetings with the director).

\subsubsection{Defining Successful Recruits}

The purpose of the camp was to allow young females to explore a variety of areas of science, with a different scientist, on each of the five days of the camp. The hope was that this interaction with scientists would encourage middle-school girls to sustain an interest in science. Successful mentorship was defined not only by the parameters of the four tenets of the Human Endeavor, as specified earlier in the NSES, but also by the general enjoyment of the class by the girls. This was demonstrated by their participation in class, journal records, conversations, and illustrations. While the camp previously demonstrated the improvement of the girls' appreciation of science (Author, 2009), the mentors who were deemed successful also helped the girls appreciate science as a discipline. The scientists were deemed unsuccessful if the girls were frustrated by the scientist's teaching, or if the girls wrote or commented on the difficulty of understanding a particular scientist.

\section{Results: How Mentor Scientists Approached their Roles with Middle-School Girls}

There seemed to be some consistencies in the ways the eight scientists approached the 
mentorship experience. For example, all the scientists were university professors, and all had a variety of experiences teaching undergraduate or graduate students. However, the scientists each had his/her own distinct style of approach to mentoring/teaching the girl's science. These approaches were different than those of classroom teachers, mainly because of the scientists' previous experiences in academia. Each scientist verbalized his/her strong desire to help the girls "like" science and see science as a real career choice, yet they all had very different approaches. Figure 2 includes (or illustrates) these approaches in the continuum.

\begin{tabular}{|c|c|c|c|}
\hline $\begin{array}{l}\text { Disseminator of } \\
\text { Knowledge }\end{array}$ & $\begin{array}{l}\text { Demonstrator of } \\
\text { Procedures }\end{array}$ & $\begin{array}{c}\text { Disseminator of } \\
\text { Activities }\end{array}$ & $\begin{array}{l}\text { Side-By-Side } \\
\text { Expert }\end{array}$ \\
\hline $\begin{array}{l}\text { Lecture based } \\
\text { on Power } \\
\text { Point } \\
\text { - } \text { Video, or } \\
\text { computer } \\
\text { assisted } \\
\text { instruction } \\
\text { Passive } \\
\text { Learners } \\
\text { Unable to } \\
\text { modify to meet } \\
\text { the needs of } \\
\text { students }\end{array}$ & 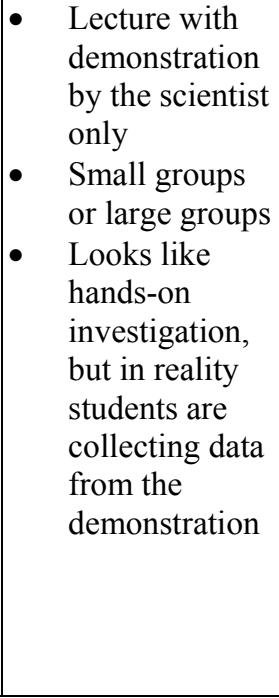 & $\begin{array}{l}\text { - Lecture } \\
\text { with activities } \\
\text { for students } \\
\text { Many } \\
\text { activities with } \\
\text { no central } \\
\text { connection } \\
\text { Looks like } \\
\text { hands-on } \\
\text { investigation, } \\
\text { but lacks } \\
\text { probing } \\
\text { inquiry } \\
\text { experience in } \\
\text { an attempt to } \\
\text { answer a } \\
\text { specific } \\
\text { question }\end{array}$ & $\begin{array}{l}\text { Mentor poses } \\
\text { question and } \\
\text { students } \\
\text { develop } \\
\text { procedures to } \\
\text { answer the } \\
\text { question. } \\
\text { - Hands-on } \\
\text { inquiry with } \\
\text { critical } \\
\text { thinking and } \\
\text { problem } \\
\text { solving. }\end{array}$ \\
\hline
\end{tabular}

Figure 2. Mentor-Approach-to-Teaching Continuum

Disseminator of Knowledge is defined as a scientist who approached the camp like a college classroom, the premise being that they (the scientist) have all the knowledge and the students are passive learners. Content Specialists who are Disseminators of Knowledge are unable to change their teaching style from the college level to the middle-school level, even with one-on-one help and guidance from the camp director for multiple years. Dr. Geraldine, for instance, the physicist, is an example of a Disseminator of Knowledge (see Table 1).

By contrast, an innate teacher is described as one who interprets reactions from students, modifies her lessons based on those reactions, and, in turn, helps students achieve new learning.

But being a successful scientist/mentor involves more than the ability to be an innate teacher. Dr. Geraldine did not have the capacity to change, despite her attempts for three years to work one-on-one with the camp director. Of the eight scientists involved with the camp, no 
one wanted to participate more than Dr. Geraldine. This project was so important to her, that she agreed to meet and work with the camp director frequently. However, after year two, she finally admitted she was unable to be anything but a Disseminator of Knowledge. However, with the director assisting her through team-teaching, Dr. Geraldine agreed to participate in year three, but only during a half-day session.

A Disseminator of Knowledge presents information and gives directions as the students remain passive. The types of presentations that the Disseminator of Knowledge typically does well are often organized according to his/her ideas of logical order, not the student's. Disseminators of Knowledge rely on verbal presentations, but what is communicated by them is not always what is perceived in the same way by the students. These types of presentations are open to interpretation by the student, and limited by the student's attention span.

A Demonstrator of Procedures is defined as a scientist who approaches teaching as a watch-and-learn experience. In this case, the scientist is usually in front of the class doing a science demonstration, and the students are positioned at a distance, usually recording data. Dr. Debbie, the soil scientist, is an example of the Demonstrator of Procedures (see Table 1). The difference between the Disseminator of Knowledge and the Demonstrator of Procedures is the shift in thinking that the students will learn more by visual than by auditory means. However, the students are still passive learners when using this approach, and the focus is still on content.

Demonstrations do have their benefits in teaching science. For instance, they can protect students from dangerous conditions. Also, demonstrations can illustrate an important concept when there is not enough lab equipment for every learner to engage personally. Remember, this was not the explicit instructions given to the science content specialists prior to their participation at camp. In fact, the camp was called "Side-by-Side with Scientists" for the very purpose of these individuals was working with the girls. Demonstrations were supposed to be kept to a minimum. A discovery demonstration in which the scientist silently conducts an experiment and allows the students to determine why the demonstration worked the way it did would have been appropriate in this setting.

In her initial meeting with the director/researcher, Dr. Debbie discussed wanting to get the girls outside, collecting soil samples and analyzing data. When she sat down and discussed further details with the camp director, her lesson proposal seemed like a perfect way for the students to investigate and experience a variety of soils. As a result, the camp director purchased the needed equipment for the class, confident that the anticipated lesson would go well. Unfortunately, the lesson proved less than envisioned.

Dr. Debbie did not allow the girls to collect their own soil samples. Rather, they watched as she did all the work. Her need for control eliminated any discovery for the girls in the experience, and while the design of the lesson demonstrated that she was listening to the director, the outcome demonstrated her perceptions were quite different. Dr. Debbie was a Demonstrator of Procedures who began with the right intentions, yet failed to broaden the girls' experiences in science because of one important detail — she neglected to let them have the experience. 
A Disseminator of Activities is defined as a scientist who also approaches mentorship like a college classroom. Knowledge is given first, then laboratory work follows, and there is little connection between the two. Dr. Juan, the earth-science professor, approached the camp in this manner (see Table 1). He seemed more focused on having the girls do "hands-on" activities, than engaging them in deep, meaningful investigation answering a particular question. When the camp director approached Dr. Juan to discuss this issue, he became frustrated, yet was willing to re-structure his lesson with the researcher's help. Even with this assistance, however, Dr. Juan had trouble comprehending children's misconceptions about science and revising his teaching methods to meet their needs.

For example, his daughter was one of the "Side-by-Side" campers, and he knew his daughter didn't get that opportunity in her school science class and so intent on having the girls engage in hands-on science activities. He provided many hands-on activities in several different content areas. One experiment was about clouds, the next about rocks, then paleontology, and the last about the atmosphere of the earth. All of this unconnected activity seemed to leave the girls puzzled, because they were not able to anticipate what was next and why. There was no logical progression to the lesson. Rather, it was a smorgasbord of Mr. Wizard-type activities, and for that reason Dr. Juan was termed a Disseminator of Activities.

The director spent much time discussing research with the scientists about students' misconceptions concerning science and the importance of prior-knowledge questions. In each meeting, the researcher reiterated the original goals of the camp to Dr. Juan. He was unwilling to accept that his lack of questioning had any relevance to what the students were learning. When the director asked him, "What do you think the girls learned from their experience with you?", his response indicated he thought the girls did learn a lot about content. The researcher/director asked him how he could be sure, since he didn't ask the girls any prior-knowledge questions before his activities. She informed him of several methods used for teaching conceptual change. Yet, he was unwilling to listen. The result was that during the next week of camp his involvement was the same lesson he had previously presented. His unwillingness to discuss the "big ideas" and inability to adjust to the girls' developmental levels kept him from becoming a "Side-by-Side" expert. His lack of appreciation for the knowledge the director had about children's misconceptions and science education as a discipline of research study made for difficult working conditions.

A Side-by-Side Expert approaches camp from the perspective of, "How can I get these girls involved in what I do?" These mentors begin with the kind of Backward Design, described by Wiggins and McTighe (2005). They focus on what they want the girls to understand about what they do as scientists. They also guide students and set up experiences for them to gain this new appreciation and understanding. In four years of the camp, three "Side-by-Side" mentors were observed: Dr. James, wetlands ecologist; Dr. Francine, chemist; and Dr. Christy, plant ecologist (see Table 1).

With the three scientists that fell into this category, students were given freedom to solve the problems presented to them in their own way. This enabled the students to use process skills in a genuine problem-solving situation, and actively be involved in first-hand learning. It was 
no coincidence that the girls reported their days with these three scientists as the most enjoyable for four consecutive years. These three scientists had achieved what the director/researcher had intended, reinforcing the idea that it was possible for middle-school girls to have an authentic "Side-by-Side" experience.

Table 1. Results of Question One: How did the science mentors approach their opportunity to mentor middle-school girls?

\begin{tabular}{|l|c|c|c|c|}
\hline & $\begin{array}{c}\text { Disseminator } \\
\text { of Knowledge }\end{array}$ & $\begin{array}{c}\text { Demonstrator } \\
\text { of Procedures }\end{array}$ & $\begin{array}{c}\text { Disseminator } \\
\text { of Activities }\end{array}$ & $\begin{array}{c}\text { Side-By-Side } \\
\text { Expert }\end{array}$ \\
\hline Dr. James & & & & $\mathrm{X}$ \\
\hline Dr. Geraldine & $\mathrm{X}$ & & $\mathrm{X}$ & \\
\hline Dr. Darlene & & & & $\mathrm{X}$ \\
\hline Dr. Francine & & & $\mathrm{X}$ & \\
\hline Scientist Joan & & & $\mathrm{X}$ & \\
\hline Dr. Christy & & & & \\
\hline Dr. Juan & & & $\mathrm{X}$ & \\
\hline Dr. Debbie & & & & \\
\hline
\end{tabular}

\section{Perspectives from the Camp Director and Implications for Classroom Teachers} Working with Science Mentors

The four years of research and practice in this domain demonstrated that it is more difficult to teach highly-trained, highly-skilled scientists to engage girls in science activities than it is to teach pre-service teachers or practicing teachers the same concepts. It is accepted that in order to be a "good science teacher" one must have pedagogical knowledge, science-content knowledge, and science-pedagogical knowledge. Yet, scientists who do not have pedagogy skills or science-pedagogical knowledge are frequently recruited to help with the teaching of science in the classroom. As this study shows, it cannot be assumed that all scientists will make good teachers or good science mentors. These "Side-by-Side" experiences of the camp director/researcher working with scientists reveal that unless the scientists value the field of education as a research field, they are not open to learning science-content pedagogy.

Scientists may perceive their roles inaccurately, and be unwilling or unable to change them. This can be a nightmare for a long-term commitment between a classroom teacher and a scientist. So how do science educators get professional scientists to best understand their role in the classroom? It was soon obvious in this unique camp setting that the scientists' perception of "teaching" and the camp director's perception of "teaching" were very different.

The scientists often assumed the girls had multiple, in-depth experiences in science prior to attending the camp. Also, an absence of prior-knowledge questions by the scientists during investigations did not allow the girls to make predictions before the experiments were 
conducted. This questioning had been a central topic in each of the scientist/director meetings prior to camp, but during actual class sessions an overall lack of questioning by the scientists led the researcher to ask, "What exactly are the girls learning?"

Several scientists spent too much class time discussing the specifics of their research instead of focusing on the overall "big idea" and where their research or content fit into the body of science knowledge as a whole. Scientists possess a wealth of knowledge about science content, but most lack an understanding of children's misconceptions concerning science, scientists, and the age-appropriateness of what they are attempting to teach. Three of the eight content specialists grasped the understanding of what it meant to work "Side-by-Side" with scientists, (e.g., giving girls responsibility for collecting data that is meaningful), but five did not. These realities led the researcher/director to create the chart of expectations below (Table 2) to share with future mentors as a means of addressing these inadequacies.

Table 2. Mentorship Expectations Guidelines

\begin{tabular}{|c|c|}
\hline What We Expect & What You Can Expect \\
\hline Question of the day? (Focus) & Girls will talk throughout the day \\
\hline $\begin{array}{c}\text { Girls will be asked to make predictions } \\
\text { and follow a procedure or a variety of } \\
\text { procedures and draw their own conclusions }\end{array}$ & Variety of academic abilities \\
\hline $\begin{array}{c}\text { Girls will be involved in collecting data as } \\
\text { they spend the day Side-by-Side } \\
\text { with you! }\end{array}$ & Girls will have misconceptions \\
\hline $\begin{array}{c}\text { You will ask the girls many questions and } \\
\text { different levels of questions about } \\
\text { what they know before giving content } \\
\text { information and/or hands-on materials }\end{array}$ & you, they will most likely do this through \\
questioning
\end{tabular}

Dr. James, who the girls reported in their journals as being extremely successful in encouraging the girls to like science, needed debriefing about his experience with young girls each time he completed a session. And this went on for six consecutive interactions. While he enjoyed the "Side-by-Side" experience tremendously, his first comment following the experience was how exhausted he was after working with young girls. He was used to teaching college students, and noted the different needs of these young learners. He needed time to remind himself that middle-school girls weren't like college students, and that his approach to teaching "Side-by-Side" required so much more energy than the traditional lecture.

Knowing this, it was helpful in constructing a visual image of the director's expectations and what the scientists could expect. Many scientists found this useful in working with the girls. For example, Dr. James was not used to the girls chatting and discussing the lesson topic while he was teaching. More comfortable with the traditional teaching methods used in his 
college classes, he expected the girls to sit quietly while he talked. Because of the different approach with "Side-by-Side" teaching, it took James some time to get acclimated to this new environment. He worked hard to improve his lessons and offer the girls a unique experience from year to year. Although a favorite scientist among the students, another reason James may have had to make some adjustments in being a role model to girls is because he is the father of three boys.

On the other hand, it cannot assume that because the scientists had female children of their own they will be able to relate to female students in a meaningful way. Recall Dr. Geraldine, who the girls reported had the most difficulty relating to the middle school females was actually the mother of two girls.

This study examined eight scientists: five Caucasian females from the United States, one Caucasian male from the United States, and two scientists from foreign countries, one male and one female. It is worth noting that the speaking accents of the two foreign scientists were mentioned in a negative way by the girls in their general discussions. One thing teachers may want to consider if working with a foreign scientist is if their accent interferes with students' learning. Also, could the accent potentially influence student's perception of the scientist in a negative way?

Other questions teachers might ask scientists when considering them for their classroom might include, "Do you have children of your own? And if so, how do you communicate your science experiences with your children? Can you speak in a child-friendly, age-appropriate way concerning your particular science discipline?"

In addition, there may be cultural barriers to address. And how does the scientist plan to take his/her information or content and make it meaningful to students? And, finally, is the material age-appropriate for middle-school students?

\section{Classroom Implications}

Scientists who are the ultimate content area specialists are often used as mentors for both teachers and students. However, when working with children, one of the reasons these relationships are not as successful as they could be is because not everyone can relate to children in an age-appropriate way. Some scientists, for example, may not be able to present their field of study in a positive light without reinforcing the common stereotypes about scientists.

In selecting a scientist for the classroom, asking the questions mentioned in this paper will help discern who would make a good science mentor for students. Teachers need some guidance in selecting appropriate mentors in order to maximize the mentors' potential influence he/she will have on students' understanding of who does science, where science is done, and what scientists do. A scientist's willingness to participate in a mentorship program or classroom situation is not sufficient in and of itself.

Second, teachers should make clear to the science mentor the goals and expectations of the proposed partnership. To do this, teacher could use Table 2 Mentorship Expectations 
Guidelines in this paper or make their own set of goals and expectations based on the needs of their classroom. And nothing should be taken for granted concerning scientists. Those scientists not in the field of education may need many discussions and reflections with the teacher to understand their role before entering the classroom.

Third, even when a scientist's roles have been clearly outlined, expect there will be a difference in what the scientist perceives and what the teacher perceives. Classroom teachers should use Figure 2.Mentor-Approach-to-Teaching Continuum as a springboard for discussion with mentor scientists. As a result, it is hoped the scientists will then begin to ask themselves, "Am I a disseminator of knowledge or disseminator of activities?" It is important that the teacher help them understand the differences.

Lastly, a good scientist role model should help students see the connection between science in the classroom and the career of a professional scientist. While in this particular study six of the eight scientists were female, it is important for students to have a role model they can relate to in science, regardless of gender. Because the researcher/director hypothesized before the investigation how important it was to expose participants to gender-matched (female) science role models, the majority of scientists participating in the "Side-by-Side" camp experience were female. The results of another study by this Author (2010) demonstrate that while the gender of mentors does play a role, it was more important for girls to have a role model who possessed the five identified characteristics of a quality mentor. These five characteristics are: a connection to why mentors became a scientist, passion for their science-content area, the ability to be an innate teacher, the ability to discuss controversial issues sensitively with young students and not bias them, and The WOW Factor.

The first of the five characteristic was a connection as to why mentors became a scientist. The "connection" is defined as one who could tell why he/she became a scientist, and do so with emotion, meaning there was a passionate bond between them and their content area. All the scientists were asked to briefly state why they had wanted to pursue science as a career. This request was made of the scientists as a means of them connecting with the young girls. Unfortunately, not all did it with sentiment, meaning passion.

Perhaps the best way to illustrate this point is by telling what occurred with a scientist who did not express a passionate bond with her content. Dr. Geraldine, a gender-matched physicist, simply told the girls, "Physics was what I was told to do." One girl asked, "Who told you to study physics?" Geraldine replied, "The government... I took a test, and that's what they said I should study." For Geraldine, her career was a practical, matter-of-fact decision tied to her Romanian culture. Even though she was a gender-matched role model, her inability to connect to this central tenet kept the girls from relating to the experiences in science she provided.

Other scientists, conversely, spoke of remembering the exact day they received their first chemistry set or about going outside to observe a pond when they were young. They told these stories with emotion and nostalgia. However, this connection alone as to why they became a scientist was not enough to encourage the girls' interests in science. The successful scientists also were similar in that they displayed a verbal and physical affinity for their 
current, professional positions.

Passion for doing what scientists do on a daily basis became the second common characteristic of the successful mentors. The passion for their daily work can be defined as the ability to see beyond the repetitive nature of one's work, to the appreciation of the possible future outcome and contribution their work will make to science as a whole.

Dr. Debbie, for instance, a gender-matched soil scientist, talked about the excitement of the experience of collecting soil samples in the field. She then described the process of taking the samples into the lab and her curiosity in reaching her study's final conclusions. All of her stories relayed passion for her daily activities.

Another positive example of this characteristic was Dr. James, a gender-mismatched role model. He discussed his passion for studying invasive species in wetlands, reporting his long field assignments and the extreme weather conditions he endured in an effort to collect his data.

The girls related best to scientists who shared stories of their travels to foreign countries. Not surprisingly, the girls were most interested in traveling to work on or near beaches and working with animals. Several commented that they could see themselves working in specific areas of science when they grow up, such as becoming a physical anthropologist or ecologist. Realizing that studying two different areas of science makes for interesting travel options may help these young females entertain the possibility of a science career.

Brickhouse et al. (2000) determined that the research scientist community was "too distant and irrelevant" for students to relate to. When the girls wrote in their journals that they wanted to pursue careers in research science fields, it demonstrates that interaction with scientists can help break down this barrier. Interesting travel stories from the scientists helped the girls internalize experiences and begin to form their own dreams.

However, describing the bond and the passion as to why someone became a scientist was not enough to encourage the girls' interests in science. The successful scientists also displayed what is called The WOW Factor. For example, the wetlands biologist, a gender-mismatched role model, while showing the girls some slides from one of his canoe trips, paused and commented, "Every time I go out in a canoe, I am wowed by nature, it's complexity and it's beauty." His appreciation and love of nature and the natural world were obvious to each of the girls. In turn, it is hoped that they, too, learn to appreciate nature in a deeper way.

Girls were most apt to like the scientists whom they viewed as fun and humorous. Baker and Leary (2003) determined that teachers play an important role, as students determine whether a class is "boring" or "fun" based upon the particular teacher. In this Side-by-Side with Scientists study, the teachers, scientists, and mentors who were fun and entertaining were able to hold the girls' attention and more easily draw them into the lessons. Being fun and having fun in class seemed to make science something the girls could relate to and enjoy as a subject of study.

While it is easy to see how the first three mentor characteristics (Connection, Passion, Wow Factor) fit together and complement one another, the fourth was extremely critical, namely, 
the role model's ability to be an innate teacher. An innate teacher is described as one who interprets reactions from students, modifies lessons based on their reactions, and, as a result, helps students achieve new learning. One of the observations of the girls in physics classes began with all the girls attentive and taking notes. But within 45 minutes, the scene changed dramatically. Discouraged by the math that accompanied physics, several of the younger girls began crying, brought to tears by their frustration. However, Dr. Geraldine, a gender-matched role model, simply kept lecturing. She only stopped when interrupted by the camp director, who had to then do quite a bit of "damage control." The girls were saying such things as, "This is too hard...," or, "I'm not smart enough for physics," or, "I'm just not good at math." An innate teacher would never have allowed the situation to get this far out of hand. She would have sensed the frustration with the students early on in her presentation, and encouraged the girls by showing them something simple they could master quickly. Instead, Dr. Geraldine went right on lecturing.

In one of the post-session discussions with the camp director, Dr. Geraldine stated an insightful realization about herself. "I used to think being a teacher was easy," she said. "I'd look at [you] education professors, and think that teaching was a relatively easy job. I mean, it's not anywhere close to studying physics. When I was growing up, my teachers made it look so easy. We'd go to school, and we'd learn. Simple as that. Now [from this experience] I see it is more difficult. Teaching is really hard work. It is not as easy as lecturing." Dr. Geraldine clearly defines herself as a researcher, not a teacher, and in this particular classroom situation that difference was evident. And obviously, by the girls' reactions, she is not an innate teacher.

Lastly, even if scientists had all of the first four characteristics, if they didn't have the ability to discuss controversial issues sensitively with the young students (and not bias them with their own beliefs), their ability to be quality role models was diminished. For example, Dr. Darlene, a gender-matched role model, wanted to make a specific point to the students on the first day of science class about the Theory of Evolution. When this ever-controversial topic surfaced, Dr. Darlene used the camp setting as a town forum, stating her own beliefs and philosophies without considering where the girls were developmentally. As a result, the following day three fewer girls showed up for camp. Their understanding and ideas about evolution were different from Dr. Darlene's, and as such they felt they couldn't continue. While there is currently an accepted idea by many scientists about evolution, the ability to discuss the topic in a non-controversial way will only aid these girls in having access to accurate scientific knowledge. Dr. Darlene's inability to engage in a give-and-take discussion, allowing these middle-school girls to express their own opinions, only served to cause their parents to remove the girls from the camp experience. It is important to note that one-third of the girls in the class were from home-school settings, and many of them have grown up with some very inaccurate ideas about science in general (e.g. Theory of Evolution). But not handling this situation sensitively only eliminated those girls from the program, restricting their life experiences.

Girls in this study had personal interactions with eight different role models, and it appears that calling scientists by their first name, like Dr. Darlene or Dr. James, rather than their last name, seemed to assist their personalization with the scientists. This author stresses that it is 
more important for a scientist to possess all five of these qualities than have the same gender as students, and recommends that when teachers look for effective mentors, they use these five characteristics as a starting point for selecting the best possible choice for a mentor or role model in science. It should be noted that none of the girls in the study mentioned the gender of the content specialist.

\section{Conclusion}

The following studies emphasized the importance of a gender- and/or ethnic-matched role model: Evans (1992), Karunanayake and Nauta (2004), and Zirkel (2002). These studies claim that gender-matched role models send students messages that gender- mismatched role models do not, and therefore, are more valuable. Lockwood (2006) found that women more often than men select gender-matched career role models, and that there was value in having a gender-matched role model who has achieved success in a traditionally male-dominated profession.

The questions asked at the beginning of this paper were several. What makes someone a good science mentor or role model? Is it the role model's education or experience that makes the difference? Is it the expertise or knowledge they possess? Do gender-matched role models offer more benefits than gender-mismatched role models? And if so, what are the benefits? And are the benefits gender-specific? These questions are important, but perhaps what is most important is the flexibility of the mentor in adapting to the goals of the mentorship. As demonstrated in this study, some mentors were unable to adapt in spite of their willingness to participate in the camp experience. The results of this research indicate that mentors can successfully provide dimensions of the human side of science for students if they have the five characteristics identified by the study. However, the author disagrees that the absence of a female role model is a barrier to middle-school girls' entry and persistence in advanced science classes and ultimately the professional science fields.

Perhaps what is most important is the flexibility of the scientists in adapting to a classroom teacher's needs. As demonstrated in this study, some scientists were unable to adapt in spite of their willingness to participate in the camp experience. Students' experiences with quality science mentors can be powerful. As teachers bring visiting scientists into the classroom, students' beliefs about science, scientists, and themselves lead to positive attitudes and less stereotypic views concerning the nature of science and the physical attributes of a scientist. The results of this research indicate that scientists can successfully provide dimensions of the Human Endeavor in classroom settings, if they are aware of the four teaching approaches as outlined, and are willing to value science educators' opinions about education, research, and their students.

Commonly held stereotypic images about scientists are in direct opposition to what students should understand about science. As identified by the National Science Education Standards (1996), learning about "Science as a Human Endeavor" begins as early as grades K-4, and is repeated in grades 5-8 and 9-12. This paper offers cautions, considerations, and guidance for educators seeking to bring science-content specialists into their classroom. 


\section{References}

American Association for the Advancement of Science. (1993). Benchmarks for science literacy: Project 2061. New York: Oxford University Press.

Barman, C. (1996). How do students really view science and scientists? Science \& Children, $30-33$.

Barman, C. (1997). Students' views of scientists and science: Results from a national study. Science and Children, 35(1), 18-23.

Bozdin, A., \& Gehringer, M. (2001). Breaking science stereotypes: Can meeting actual scientists change students' perceptions of scientists? Science \& Children, 38, 24-27.

Buck, G., Plano. C. V., Leslie-Pelecky, D., Lu, Y., \& Cerda-Lizarraga, P. (2007). Examining the cognitive processes used by adolescent girls and women scientists in identifying science role models: A feminist approach. Science Education. 92(4), 688-707. http://dx.doi.orrg/ $10.1002 /$ sce. 20257

Chambers, D. W. (1983). Stereotypic images of the scientist: The Draw-a-Scientist Test. Science Education, 67(2), 255-265.

Evans, M. O. (1992). An estimate of race and gender role-model effects in teaching high school. Journal of Economic Education, 23, 209-217.

Farland-Smith, D. (2012). Personal and social interactions between young girls and scientists: Examining critical aspects for identity construction. Journal of Science Teacher Education, 23, 1-18. http://dx.doi.orrg/10.1007/s10972-011-9259-7.

Farland-Smith, D. (2009). Exploring middle school girls' science identities: Examining attitudes, and perceptions of scientists when working 'side-by side' with scientists. School Science and Mathematics, 109(7), 412-421.

Finson, K. D. (2002). A multicultural comparison of draw-a-scientist test drawings of eighth graders. Paper presented at the Annual International Conference of the Association of Educators of Teachers of Science. Charlotte, NC.

Flick, L. (1990). Scientist in Residence program: Improving children's images of science and scientists. School Science Mathematics, 90(3).

Fort, D. C., \& Varney, H. L. (1989). How students see scientists: Mostly male, mostly white, mostly benevolent. Science \& Children, 26(8), 8-13.

Galbo, J. J. (1989). The teacher as a significant adult: A review of literature. Adolesence, 24, 549-556.

Gibbs, R. (2010). President Obama expands "educate to innovate" campaign for Excellence in Science, Technology, and Engineering (STEM) education. The White House, Officce of Press Secretary. Retrieved from http://www.whitehouse.gov/the-press-office/presidentobama-expands-educate-innovate-campaign-excellence-science-technology-eng 
Kafai, Y. B., \& Gilliland-Swetland, A. J. (2000). The use of historical materials in elementary science classrooms. Science Education, 85(4), 349-367.

Karplus, R. (1970). Science curriculum improvement study-a program report. Berkley: Educational Products Information Exchange Institute.

Karunanayake, D., \& Nauta, M. M. (2004). The relationship between race and students' identified career role models and perceived role model influence. Career Development Quarterly, 52, 225-234.

King. M. M., \& Multon, K. D. (1996). The effects of television role models on the career aspirations of African American junior high school students. Journal of Career Development, 23, 111-125.

Kuhn, T. S. (1972). The structure of scientific revolutions (2nd ed). University Press, Chicago.

Lockwood, P. (2006). Someone like me can be successful: Do college students need same gender role models? Psychology of Women Quarterly, 30, 36-46.

Mead, M., \& Metraux, R. (1957). The image of the scientist amongst high school students. In B. Barbar \& W. Hirsch (Eds.), The Sociology of Science, 38-61. Lewes, England: Falmer Press.

National Research Council (NRC). (1996). National science education standards. Washington, DC: Academic Press.

National Research Council (NRC). (2012). A Framework for K-12 science education. Practices, Crosscutting Concepts, and core ideas. Washington, D.C.: National Academy Press.

Nauta, M. M., Epperson, D. L., \& Kahn, J. H. (1998). A multiple-groups analysis of the predictors of higher level career aspirations among women in mathematics, science, and engineering majors. Journal of Counseling Psychology, 45(4), 483-496.

Schibeci, R. A., \& Sorenson, I. (1983). Elementary school children's perceptions of scientists. School Science Mathematics, 83(1), 14-19.

Solnick, S. J. (1995). Changes in women's majors from entrance to graduation at women's and coeducational colleges. Industrial Labor Relations Review, 48, 515-546.

Wiggins, G., \& McTighe, J. (2005). Understanding by design (2nd ed.). Association for Supervision \& Curriculum Development, Alexandria, VA.

Wilcoxson, I. U., \& Phelps, C. L. (2004). Recruiting future neuroscientists:What asking the recruits can teach us. Neuroscience and Society, 10, 594-597.

Zirkel, S. (2002). Is there a place for me? Role models and academic identity among White students and students of color. Teachers College Record, 104, 357-376. 


\section{Copyright Disclaimer}

Copyright reserved by the author(s).

This article is an open-access article distributed under the terms and conditions of the Creative Commons Attribution license (http://creativecommons.org/licenses/by/3.0/). 